\title{
The position of the Chilean Medical Association with respect to torture as an instrument of political repression
}

\author{
Gunther Seelmann Santiago, Chile
}

In 1986 we were invited by the Danish Physicians Association and the Rehabilitation and Research Centre for Torture Victims to express our points of view on human rights and, specifically, on the important subject of the participation of doctors in reprehensible practices in violation of human rights. Our Secretary General at that time, Dr Francisco Rivas, was unable to attend the event, as he was in prison. Nonetheless, his report was received by the delegates, who demonstrated great solidarity and support for the directors of the Civil Assembly who were under arrest, including Dr Rivas and Dr Juan Luis Gonzáles. It is important to recall that the Civil Assembly led the mobilisation against the dictatorship of General Augusto Pinochet during the period from 1983 to 1987.

During this period, the political repression exercised by Chilean security forces reached its peak of severity and intensity. It was during this period that arsenals were found in the northern region of the country, and that an attempt was made on the life of the dictator. Repressive acts during these years were of an especially violent nature, taking the form of a hunting down of people comparable only to that experienced in Chile in the months immediately following the military coup in 1973. This persecution also involved the massive destruction of poor communities throughout an extensive area of the country. An estimated 100 people under political arrest were subjected to the most brutal forms of torture. According to the report made by $\mathrm{Dr}$ M D Madariaga of Cintras, a Chilean human rights Organisation, which treats victims of torture, the experience endured by these people was 'an irrational and inhuman offence against their basic integrity'. Their arrest was followed by torture and solitary confinement for periods of up to two months. Prolonged isolation is a method that, according to $\mathrm{E}$ Neumann, 'aims to lead the individual to conditions of physiological exhaustion, defencelessness and humiliation, which gradually deteriorate one's selfesteem, autonomy and will, as the victim is left unprotected against his or her tormenters'. Through the Pidee Foundation, a Chilean human rights institution with long experience in rehabilitating infants and adolescents who have been the direct or indirect victims of political repression, I had the opportunity to meet some of these victims' families, who were being assisted in La Serena. We (S Herrera and G Seelmann) examined 30 children in 60 per cent of whom we detected emotional instability and severely retarded levels of affection and sociability. Five children demonstrated signs of acute distress, fear or depression; there were also two cases of enuresis and one of multiple somatic reactions.

In the period 1983-1987, the number of political prisoners under the authoritarian regime fluctuated between 400 and 500 . It is estimated that approximately 80 per cent of the prisoners were tortured, with five doctors and three nurses included iQ this percentage.

The country's socio-political setting was altered as result of the opposition victory in the plebiscite held in October of 1988 and the presidential and parliamentary elections held in December 1989. General Pinochet was defeated and has been succeeded as President of the Republic; yet he maintains the position of Commander in Chief of the Armed Forces The transition to democracy is impeded by his continued presence in a position of importance, as well as by the legal and economic restrictions which are the legacy of the former regime. How has the Chilean Medical Association confronted this situation?

In the first place, through concern for our colleagues who are under political arrest, currently numbering three: Drs Pedro Marín, Alejandro Aravena and Pedro Ubilla. Secondly, by raising consciousness among our associates with regard to human rights violations which have affected doctors, such as arrests, torture, dismissals and other arbitrary actions. We have organised diverse activities aimed at spreading the doctrine of human rights among Chilean doctors, coordinating these activities with other human rights bodies, both national and international. Among the actions which have been taken are denouncements of violations of fundamental rights, and exchanges of information, as well as research and documentation. We have also lent support to doctors returning to the country after many years in forced exile, helping them to resolve the numerous problems surrounding the personal readjustment of their families and their reintegration into the labour force.

At present there remain several extremely delicate 
issues, such as granting of pardons to the perpetrators of serious crimes committed by members of the armed forces, the police and security forces of the former regime. The main obstacles to the further investigation of these sanctions or pardons are the military justice apparatus, which still maintains an excessive degree of authority, and a civil judicial system which does not yet guarantee fair proceedings - a considerable number of non-democratic judges remain active in the system. Considering the situation from our perspective, we believe there can be neither stable democracy nor peaceful co-existence in our society until a firm basis of truth and justice is reached.

At present 295 political prisoners remain in Chilean prisons, representing a flagrant contradiction for a democratic regime. The political initiative to put an end to this situation exists within the government of Patricio Aylwin and the recently elected parliament. However, pressures from the armed forces and the rightist majority within the senate continue to impede the granting of freedom to those arrested for political reasons.

We reaffirm before this international court our most categorical rejection of torture. Likewise, we reiterate our resolute support of the diverse initiatives aimed at investigating the participation of doctors in these unacceptable and condemnable practices, and the sanctioning of these activities within the medical profession and scientific organisations. The agreements reached on this subject by the Permanent Committee of Physicians of the European Community give positive indications regarding their support of our association.

We will maintain a critical and vigilant attitude with regard to this subject. We have publicly declared our willingness to receive claims against doctors involved in torture or other human rights violations, which will be submitted to internal proceedings for the determination of guilt or innocence.

There exists irrefutable proof that, during the 16 years of dictatorship, doctors and other members of the health care professions caused brutal suffering to their peers. Doctors involved in acts of torture are, for the most part, members of the armed forces. The conduct of these professionals is the result of the displacement of their medical vocation by the doctrine of 'national security', which conceives of the masses and their social and political organisations as the internal enemy'.

It is indispensable for our country to put an end to this ideological substratum and to integrate military doctors into the national health care system.

In addition, the professional associations must recuperate their status as public law associations, which they lost during the dictatorship, thus enabling them to investigate and process the ethical transgressions committed by their associates with the greatest possible degree of legal support.

Gunther Seelmann, MD, is Chairman of the Department of Human Rights, The Chilean Medical Association, Santiago, Chile. 